Cold Spring Harb Perspect Biol; doi: 10.1101/cshperspect.a035717

\title{
Corrigendum: Niche Cells and Signals that Regulate Lung Alveolar Stem Cells In Vivo
}

\author{
Nicholas H. Juul, Courtney A. Stockman, and Tushar J. Desai
}

In the first version of this article, there was a typographical error on p. 9 of the PDF. The phrase "haploinsufficiency of FGFR2c" (lines 16-17 in the right-hand column) should have been "haploinsufficiency of FGFR2." The authors apologize for this error. The phrase has been corrected in the current version of the article.

Copyright $\odot 2020$ Cold Spring Harbor Laboratory Press; all rights reserved; doi: 10.1101/cshperspect.a040303 Cite this article as Cold Spring Harb Perspect Biol 2020;12:a040303 


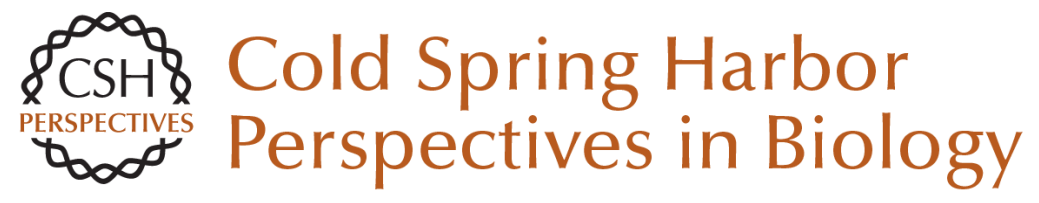

\section{Corrigendum: Niche Cells and Signals that Regulate Lung Alveolar Stem Cells In Vivo}

Nicholas H. Juul, Courtney A. Stockman and Tushar J. Desai

Cold Spring Harb Perspect Biol 2020; doi: 10.1101/cshperspect.a040303

Subject Collection

For additional articles in this collection, see http://cshperspectives.cshlp.org/cgi/collection/

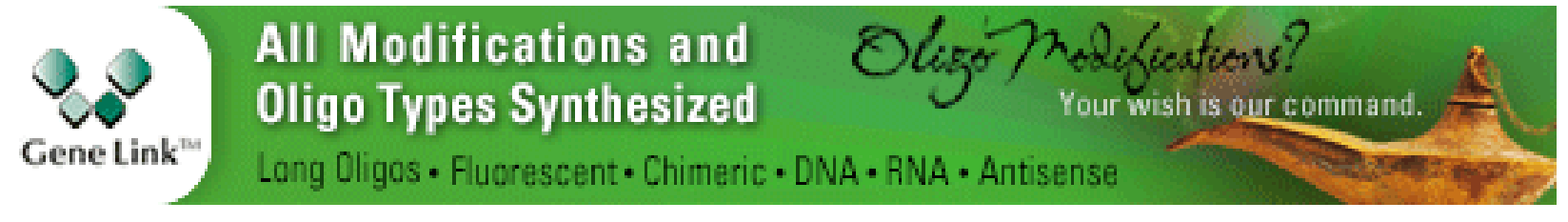

Copyright @ 2020 Cold Spring Harbor Laboratory Press; all rights reserved 